\title{
Antiproliferative and antiapoptotic effect of thymoquinone on cancer cells in vitro
}

\author{
Kus $\mathrm{G}^{1}$, Ozkurt $\mathrm{M}^{2}$, Kabadere $\mathrm{S}^{2}$, Erkasap $\mathrm{N}^{2}$, Goger $\mathrm{G}^{3}$, Demirci $\mathrm{F}^{4}$ \\ Anadolu University, Department of Health, Faculty of Open Education, Eskisehir, Turkey. \\ gokhankus@anadolu.edu.tr
}

\begin{abstract}
OBJECTIVES: Nigella sativa oil and thymoquinone were comparatively tested in vitro for their effects on human cancer cell lines (glioma,T98; prostate, LnCaP) as well as mouse embryonic fibroblast cell lines (3T3), and for the induction of apoptosis.

METHODS: Individual cell lines were treated with thymoquinone and $N$. sativa oil for 24 and $48 \mathrm{hr}$. Survival rate with MTT, apoptosis with flow cytometry and caspase-9 mRNA enzyme levels with RT-PCR were determined in vitro.

RESULTS: Application of respective concentrations of $N$. sativa oil (excluding $100 \mu \mathrm{g} / \mathrm{mL}$ for $48 \mathrm{hr}$ ) did not change the number of tested cell lines, however, treatment with thymoquinone reduced the number of all cells significantly. Thymoquinone also exerted its apoptosis inducing effect through the activation of caspase-9.

CONCLUSION: Differing with the type of cancer cells, thymoquinone posseses a strong contentration and time dependent survival reducing effect on cancer cells via apoptosis (Fig. 6, Ref. 22). Text in PDF www.elis.sk. KEY WORDS: thymoquinone, in vitro, apoptosis, antiproliferative, anticancer.
\end{abstract}

\section{Introduction}

The plague of this century, "cancer" is a group of complex pathologies and diseases characterized by "out of control" cell growth (1). During apoptosis, a variety of molecules with up-regulatory and down-regulatory properties have a dynamic interaction and can inhibit pro-apoptotic molecules or apoptotic factors. And cancer is caused by uncontrolled cell proliferation or failure of cells to pass through the apoptotic cell death (2-4). As a consequence, compounds which may trigger cancer cell apoptosis may lead to promising future drugs for the treatment of cancer.

Nigella sativa, well known also as black cumin seed of the Ranunculaceae is an annual plant, has a long history in traditional medicine with therapeutic effects including analgesia, antihypertensive, anti-eczema, diuretic, antimicrobial, gastrointestinal problems as well as in various cancer therapies (5).

Thymoquinone is one of the bioactive components of Nigella sativa seed oil and has a wide range of biological and pharmacological activities including anti-cancer, anti-tumoral, anti-oxidant and anti-proliferative properties. In vitro and in vivo pharmacologi-

${ }^{1}$ Anadolu University, Department of Health, Faculty of Open Education, Eskisehir, Turkey, ${ }^{2}$ Eskisehir Osmangazi University Department of Physiology, Faculty of Medicine, Eskisehir, Turkey, ${ }^{3}$ Trakya University, Faculty of Pharmacy, Department of Pharmacognosy, Edirne, Turkey, and ${ }^{4} \mathrm{An}-$ adolu University, Faculty of Pharmacy, Department of Pharmacognosy, Eskisehir, Turkey

Address for correspondence: G. Kus, Anadolu University Open Education Faculty, Yunus Emre Campus 26480 Eskisehir, Turkey. cal studies have been reported for their potential antidiabetic (6), neuroprotective (7), cardiovascular (8), gastroprotective, hepatoprotective (9) activities among others (10). Since there has baeen no encountered study examining the possible role of thymoquinone on glioma (T98), prostate cancer cells ( $\mathrm{LnCaP})$ and mouse embryonic fibroblast cell line (3T3), we tried to reveal its role on these cell lines in vitro.

\section{Materials and methods}

\section{General}

Thymoquinone was obtained from commercial sources in high purity (> $98 \%$, Sigma-Aldrich) whereas Nigella sativa oil was obtained from local producer ( $>10 \%$ thymoquinone, AweCemre, Tokat, Turkey). Both samples were dissolved individually in dimethyl sulfoxide (DMSO, Sigma) and diluted further with Dulbecco's modified Eagle's medium (DMEM, Sigma) to obtain the required final concentrations for the assays listed below in detail.

\section{Cell culture}

T98, LnCaP and 3 T3 cells were obtained from the American Type Culture Collection (ATCC, USA) and grown in complete medium containing DMEM supplemented with $10 \%$ fetal calf serum (FCS, Sigma) and $1 \%$ penicillin (10000 unit)-streptomycine $(10 \mathrm{mg} / \mathrm{ml})$ solution (Sigma) in a humidified atmosphere of $95 \%$ $\mathrm{O}_{2}$ and $5 \% \mathrm{CO}_{2}$ in air at $37{ }^{\circ} \mathrm{C}$. After confluence achieved more than $95 \%$, the cells were detached with $0.25 \%$ trypsin-EDTA (Sigma), centrifuged at $1200 \mathrm{rpm}, 4^{\circ} \mathrm{C}$ for $5 \mathrm{~min}$ and counted with 


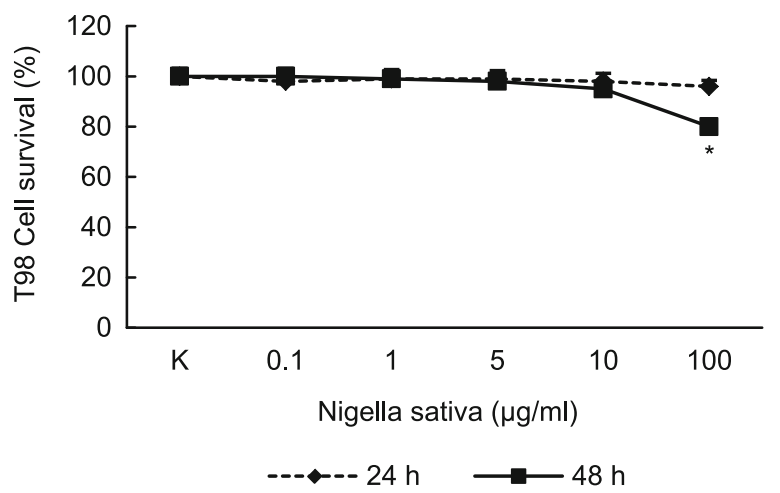

Fig. 1. Treatment of T98 cells with Nigella sativa oil for 24 and $48 \mathrm{hr}$.

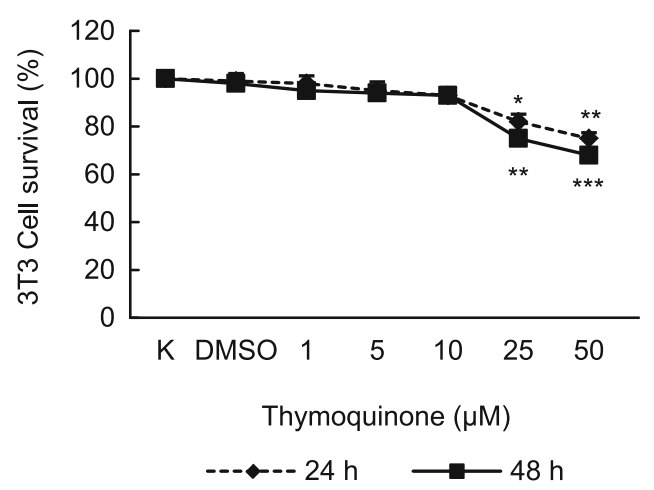

Fig. 2. Effects of Thymoquinone and DMSO (vehicle) on 3 T3 cell survival during 24 or $48 \mathrm{~h}$ treatments. ${ }^{*} \mathrm{p}<0.05,{ }^{* *} \mathrm{p}<0.01,{ }^{* * *} \mathrm{p}<0.001$.

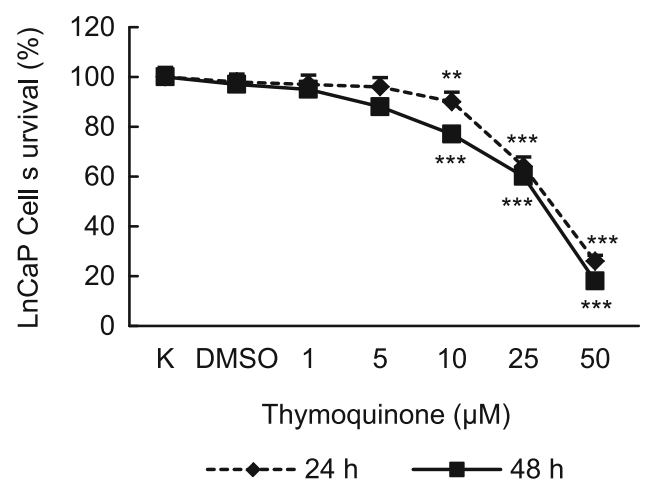

Fig. 3. The influence of Thymoquinone on LnCaP cells survival after 24 or $48 \mathrm{~h}$.

a cell counter (CEDEX, Roche). The cells were then transferred to microplates for cell survival studies and to flasks for apoptosis and caspase measurements.

\section{Test groups}

Test groups were assigned as follows: control (complete medium only); dimethly sulfoxide (DMSO) (complete medium with a final concentration of $0.1 \% \mathrm{DMSO}$, solvent); thymoquinone (treated with $1,5,10,25$ and $50 \mu \mathrm{M}$ for 24 or $48 \mathrm{hr}$ ) and $N$. sativa oil $(0.1,1,5,10$ and $100 \mu \mathrm{g} / \mathrm{mL}$ for 24 and $48 \mathrm{hr})$.

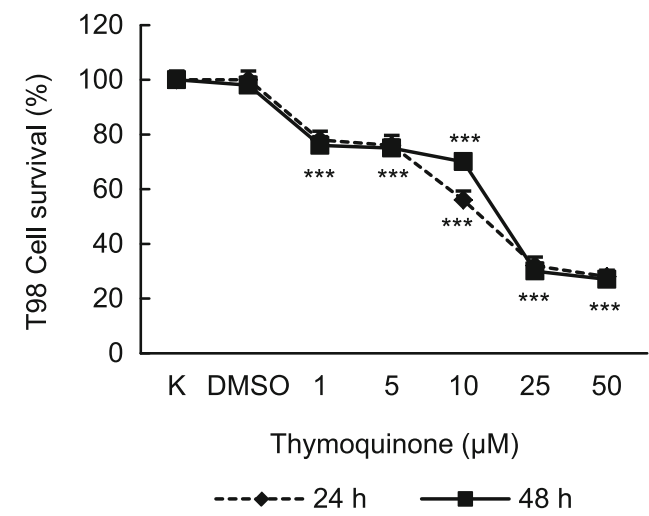

Fig. 4. The activity of $1,5,10,25$ and $50 \mu \mathrm{M}$ thymoquinone on cell survival of T-98 cells by using MTT after 24 or $48 \mathrm{~h}$.

\section{Cell survival}

The effects of thymoquinone and Nigella sativa oil on cell survival were determined by 3-[4,5-dimethylthiazol-2yl]-diphenyl tetrazolium bromide (MTT, Sigma) colorimetric assay (11). MTT test was applied and cell survival was determined by measuring the formazan absorbance at $550 \mathrm{~nm}$ with a microplate reader (BioTek; Winooski,VT). Since the number of cells in each well is proportionate to the absorbance of the soluble formazan, the optical density read from the drug-treated wells was converted to the percentage of live cells versus control using the following formula:

Absorbance of treated cells in each well x $100 /$ the mean absorbance of control cells.

\section{Flow cytometric analysis}

To determine cell death type (necrosis or apoptosis) of cells, we used flow cytometric analysis with the 25 and $50 \mu \mathrm{M}$ thymoquinone doses that diminish cell survival by more than fifty percent. Apoptotic cells were determined by staining with fluorescein isothiocyanate (FITC)-labeled Annexin V (Invitrogen) and subsequent flow cytometric analysis. Alive cells are negative for both PI and Annexin V, early apoptotic cells are PI negative but Annexin $\mathrm{V}$ positive while dead/late apoptotic cells are positive for both PI and Annexin V.

\section{RNA extraction and determination of caspase- 9 mRNA levels}

The expression of caspase- 9 mRNA was examined in control and thymoquinone treated cells. The mRNA levels of caspase- 9 in relation to the housekeeping gene was determined by qT-PCR with TaqMan probes. RT-+PCR data were collected using the Roche lightcycler nano system.

\section{Statistical analysis}

All results are the mean of at least three independent assays and the $\mathrm{p}$ value less than 0.05 was considered to be significant for MTT results. Data were expressed as the mean percent fraction of control \pm standart error of mean. Statistical significance ascertained by one way analysis of variance followed by Tukey's multiple comparison test. The apoptotic results were depicted as 

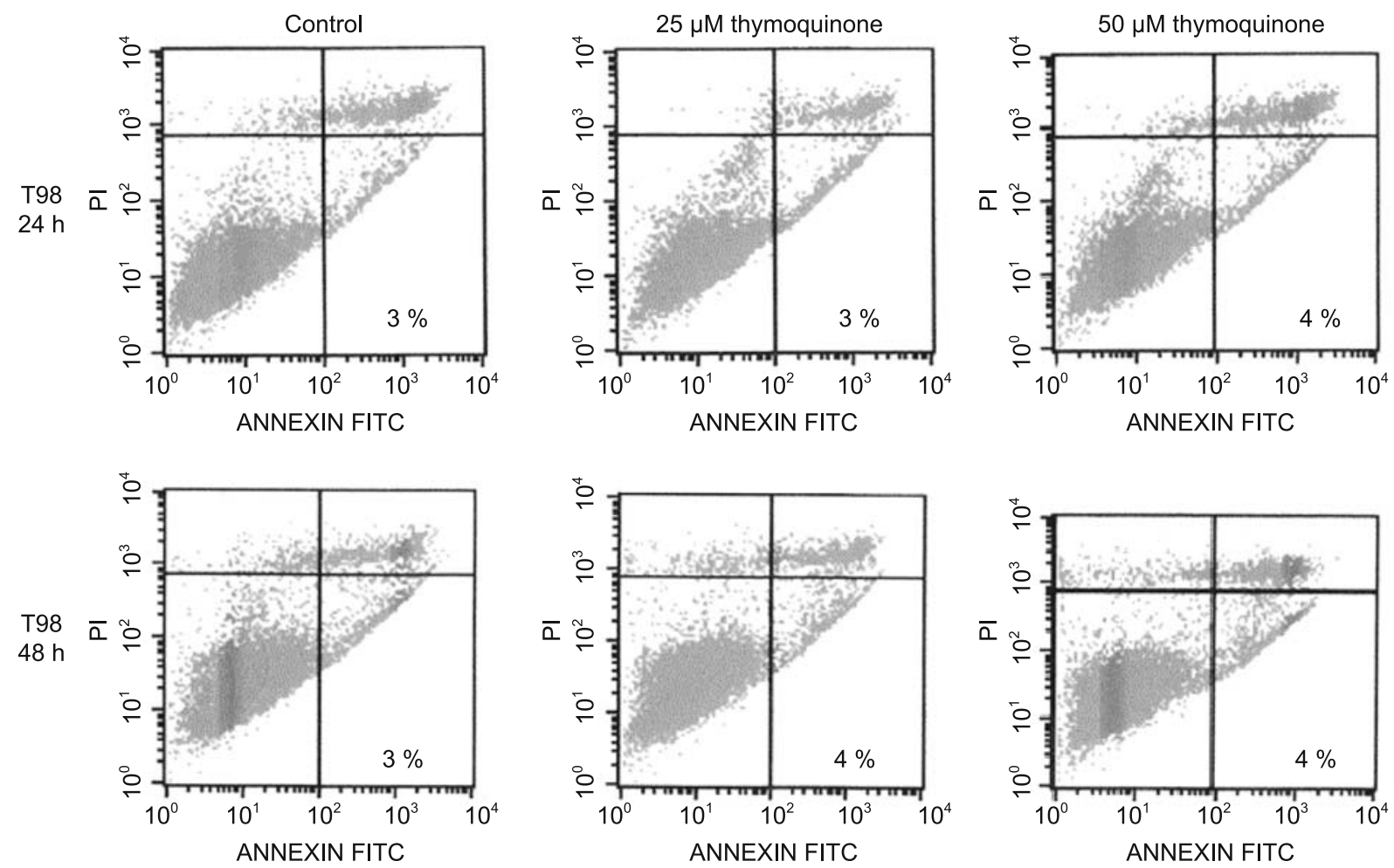

Fig. 5. T-98G cells, treated or non-treated with 25 or $50 \mu \mathrm{M}$ Thymoquinone for 24 (A) or 48 (B) h, then stained with FITC Annexin V apoptosis assay kit with PI (Invitrogen). Lower left sections of all the Figure, AnnexinV/PI (-), living cells; lower right sections of all the Figure, AnnexinV (+)/PI (-), early apoptotic cells; upper left sections of all the figüre, Annexin (-)/PI (+), necrotic cells; upper right sections of all the Figure, Annexin $(+) / P I(+)$, late stages of apoptosis and secondary necrosis. Results of only one independent experiment out of 3 is pointed.

percentage of cells. RT-PCR results were calculated by GraphPad software program. Transcript data were expressed relative to the control standart deviation.

\section{Results}

\section{Cell viability assays}

Treatment of the cells with DMSO did not cause any significant change in cell viability in pilot studies. Viability of T98, Ln$\mathrm{CaP}$ and 3T3 cells was not changed after treatment with Nigella sativa oil for $24 \mathrm{hr}$. Culturing of cells with $100 \mu \mathrm{g} / \mathrm{mL}$ of Nigella sativa oil for $48 \mathrm{hr}$ reduced the number of only T98 cells by $20 \%$ (Fig. 1). However, treatment of cells with 1, 5, 10, 25 and $50 \mu \mathrm{M}$ thymoquinone reduced the number of cells by $98,95,93,82(\mathrm{p}<$ $0.5)$ and $75 \%(\mathrm{p}<0.01)$ for $3 \mathrm{~T} 3$ cells (Fig. 2); 97, 96, 90, $64(\mathrm{p}<$ $0.01)$ and $26(\mathrm{p}<0.001)$ for LnCaP cells (Fig. 3) and 78, 76, 56, 32 and $28(\mathrm{p}<0.001)$ for T98 cells (Fig. 4) for $24 \mathrm{hr}$, respectively. For $48 \mathrm{hr}$ these rates were 95, 94, 93, $75(\mathrm{p}<0.01)$ and $68 \%$ $(\mathrm{p}<0.001)$ for $3 \mathrm{~T} 3$ cells (Fig. 2); 95, 88, 77, 60 and $18(\mathrm{p}<0.001)$ $\%$ for LnCaP cells (Fig. 3) and 76, 75, 70, 30 and $27(\mathrm{p}<0.001)$ $\%$ for T98 cells (Fig. 4) for $48 \mathrm{hr}$.

\section{Flow cytometric analysis and gene expression}

To further investigate the underlying mechanism of reduction of cell survival detected with MTT assay, we examined the apoptotic effect of the thymoquinone on cancer cells using flow cytometric analysis with 25 and $50 \mu \mathrm{M}$ thymoquinone that decreases cell survival by more than $50 \%$. As seen in Figs 5 and 6, time and concentration dependent apoptosis of LnCap cells, not T98 cells, was detected. The analysis after $24 \mathrm{hr}$ treatment with 25 and $50 \mu \mathrm{M}$ thymoquinone demonstrated that $2 \%$ and $23 \%$ of the LnCaP cells underwent early apoptosis, whereas 3 and $76 \%$ of the cancer cells underwent early apoptosis after $48 \mathrm{hr}$ treatment. Caspase-9 mRNA level was increased in $\mathrm{LnCaP}$ cellline treated with 25 and $50 \mu$ Mthymoquinone $(p>0.05)$ whereas notchanged in T98 cell line.

\section{Discussion}

There are increasing number of scientific studies on the relationship between thymoquinone and cancer. In vitro and in vivo pharmacological studies have been reported for their potential antitumor, anticancer (12), antidiabetic (13), cardiovascular activity (8), gastroprotective, anti-inflammatory, hepatoprotective activity (9) and pulmonary activity (14).

Several other studies demonstrated that thymoquinone, one of the most active components in Nigella sativa seed, inhibits the proliferation of various cancer cell lines. Thymoquinone diminished cell survival and induced apoptosis of canine osteocarcinoma cells, human breast adenocarcinoma (MCF7) and human ovarian 

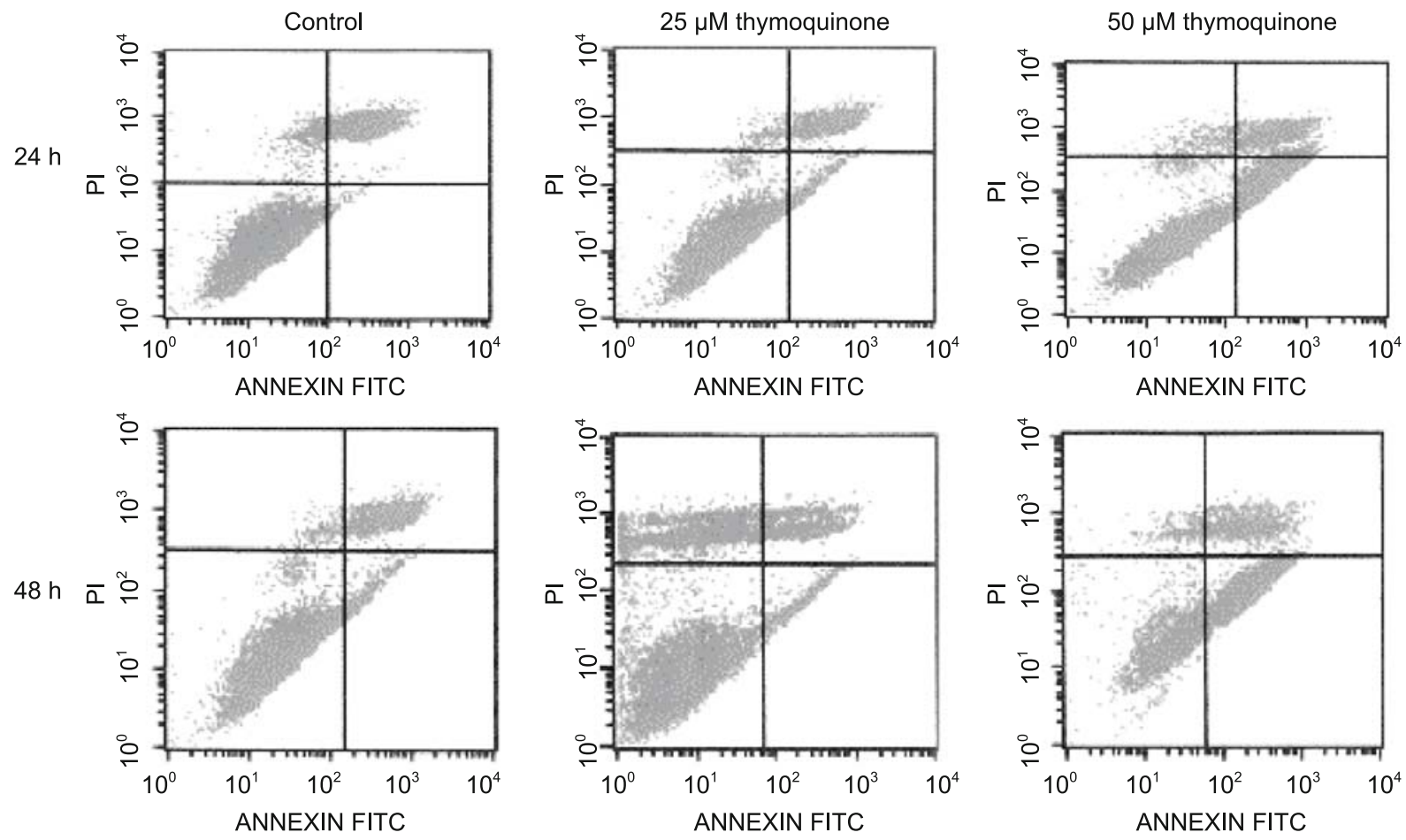

Fig. 6. The activity of 25 and $50 \mu M$ Thymoquinone on apoptosis of LnCaP cells by using Annexin V-FITC/PI after 24 or 48 h.

adenocarcinoma (BG-1) (15). Similarly, thymoquinone has been shown to inhibit cell proliferation in cultured cells derived from myeloblastic leukemia cells, fibrosarcoma cells, laryngeal neoplastic cells, pancreatic cells and human colon cancer cells $(16,17$, $18,19,20)$. El-Mahdy et al. showed that thymoquinone induced apoptosis is p53-independent and occurs through the activation of caspase 3, 8 and 9 (21). In contrast, normal cells and primitive mouse keratinocytes are resistant to the apoptotic and antiproliferative effects of thymoquinone and their lack of significant changes in morphology and proliferation confirms the selectivity of this compound for cancer cells $(15,22)$.

According to our results, $N$. sativa oil did not affect the survival of cancer cells and 3T3 cells, however thymoquinone diminishes survival rate and induces apoptosis of only $\mathrm{LnCaP}$ cells in vitro and it possibly this effect through caspase-9. However, thymoquinone did not show the same effects on T98 and 3T3 cells. Our study shows thymoquinone has strong dose, time and cancer type dependent effects through decreasing cell survival and inducing apoptosis in prostate cancer cells. Although much work is needed, our data provides evidence of potential implications for the application of thymoquinone as a novel possible antiproliferative drug against prostate cancer.

\section{References}

1. Clark HP, Carson WF, Kavanagh PV, Ho CPH, Shen P, Zagoria RJ. Staging and current treatment of hepatocellular carcinoma. Radi Graphics, $2005 ; 25$ : $3-23$.
2. Salseven GS, Dixit VM. Caspase activation: The induced proximity model. Proc Natl Acad Sci USA 1999; 96: 10964-10967.

3. Huerta S, Gaulet EJ, Haerta-Yepez S, Livingston EH. Screening and detection of apoptosis. J Surg Res 2007; 1: 143-156.

4. Herr I, Debatin KM. Cellular stress response and apoptosis in cancer therapy. Blood 2001; 98: 2603-2614

5. Ahmad A, Husain A, Mujeeb M et al. A review on therapeutic potential of Nigella sativa: A miracle herb. Asian Pacif J Tropic Biomed 2013; 3 (5): 337-352.

6. Mathur ML, Gaur J, Sharma R, Haldiya KR. Antidiabetic properties of a spice plant Nigella sativa. J Endocrinol Metabol 2011; 1 (1): 1-8.

7. Ezz HSA, Khadrawy, YA, Noor NA. The neuroprotective effect of curcumin and Nigella sativa oil against oxidative stress in the pilocarpine model of epilepsy: a comparison with valproate. Neurochem Res 2011; 36 (11): 2195.

8. Tasawar Z. Siraj Z, Ahmad N, Lashari MH. The effects of Nigella sativa (Kalonji) on lipid profile in patients with stable coronary artery disease in Multan, Pakistan. Pak J Nutr 2011; 10 (2): 162-167.

9. Al-Suhaimi EA. Hepatoprotective and immunological functions of Nigella sativa seed oil against hypervitaminosis A in adult male rats. Int J Vitam Nutr Res 2012; 82 (4): 288-297.

10. Gholamnezhad, Z., Havakhah, S., Boskabady, M. H. Preclinical and clinical effects of Nigella sativa and its constituent, thymoquinone: A review. J Ethnopharmacol 2016; 190: 372-386.

11. Mossmann T. Rapid colorimetric assay of cellular growth and survival: Application to proliferation and cytotoxicity assay. J Immun Method 1983; 65: 55-63. 


\section{2-316}

12. Khan A, Chen H, Tania M, Zhang D. Anticancer activities of Nigella sativa (black cumin). Afr J Trad Complement Altern Med 2011; 8 (5S).

13. Mathur ML, Gaur J, Sharma R, Haldiya KR. Antidiabetic properties of a spice plant Nigella sativa. J Endocrinol Metab 2011; 1 (1): 1-8.

14. Al-Sheddi ES, Farshori NN, Al-Oqail MM, Musarrat J, Al-Khedhairy AA, Siddiqui MA. Cytotoxicity of Nigella sativa seed oil and extract against human lung cancer cell line. Asian Pac J Cancer Prev 2014; 15 (2): 983-987.

15. Shoieb AM, Elgayyar M, Dudrick PS, Bell, JL, Tithof PK. In vitro inhibition of growth and induction of apoptosis in cancer cell lines by thymoquinone. Int J Oncol 2003; 22 (1): 107-113.

16. Ivankovic S, Stojkovic R, Jukic M, Milos M, Milos M, Jurin M. The antitumor activity of thymoquinone and thymohydroquinone in vitro and in vivo. Exp Oncol 2006; 28 (3): 220-224.

17. Womack K, Anderson M, Tucci M, Hamadain E, Benghuzzi H. Evaluation of bioflavonoids as potential chemotherapeutic agents. Biomed Sci Instrum 2006; 42: 464-469.
18. Tan M, Norwood A, May M, Tucci M, Benghuzzi H. Effects of (-) epigallocatechin gallate and thymoquinone on proliferation of a PANC-1 cell line in culture. Biomed Sci Instrum 2006; 42: 363-371.

19. Banerjee $S$ et al. Review on molecular and therapeutic potential of thymoquinone in cancer. Nutrit Cancer 2010; 62 (7): 938-946.

20. Majdalawieh AF, Fayyad MW, Nasrallah GK. Anti-cancer properties and mechanisms of action of thymoquinone, the major active ingredient of Nigella sativa. Crit Rev Food Sci Nut 2017; accepted for publication.

21. El-Mahdy MA, Zhu Q, Wang QE, Wani G, Wani AA. Thymoquinone induces apoptosis through activation of caspase- 8 and mitochondrial events in p53-null myeloblastic leukemia HL-60 cells. Int J Cancer 2005; 117 (3): 409-417.

22. Gali-Muhtasib HU, Kheir WGA, Kheir LA, Darwiche N, Crooks PA. Molecular pathway for thymoquinone-induced cell-cycle arrest and apoptosis in neoplastic keratinocytes. Anti-cancer Drugs 2004; 15 (4): 389-399. 